Point of View

\title{
THE RISK OF EROSION IN BRAZILIAN CULTIVATED PASTURES
}

\author{
${\text { Gerd Sparovek }{ }^{1 *} \text {; Vladia Correchel2; Alberto G.O. Pereira Barretto }}^{3}$ \\ ${ }^{1}$ USP/ESALQ - Depto. de Ciência do Solo, C.P. 9 - 13.418-900 - Piracicaba, SP - Brasil. \\ ${ }^{2} U F G / E A$, C.P. 131 - 74.001-970 - Goiânia, GO - Brasil. \\ ${ }^{3}$ USP/ESALQ - Programa de Pós-Graduação em Solos e Nutrição de Plantas. \\ *Corresponding author <gerd@esalq.usp.br>
}

\begin{abstract}
Pastures are normally associated with minor erosion problems because of their efficient soil cover. Soil cover is without doubt the most effective inter-rill and rill erosion control practice. However, considering the frequency at which pastures are replanted in Brazil and their enormous territorial extension (178 million hectares) we identify that extensive areas, usually covered by pastures, will remain bare, intensively tilled, and without complementary mechanical soil control practices. The pasture area is equivalent to that occupied by most important Brazilian annual crops (corn or soybeans), that are usually cultivated under no-tillage or supported by governmental soil conservation programs. The precise assessment of these impacts, caused by the estimated 10 million hectares of the yearly replanted pastures is unknown, and there is lack of scientific knowledge to suggest an adequate solution. This is, probably, the greatest challenge of Brazilian soil conservation and for an adequate resolution, will require a joint effort of researchers, technicians, educators and stakeholders.

Key words: environmental impact, soil conservation research
\end{abstract}

\section{DIMENSÃO DOS IMPACTOS CAUSADOS PELA EROSÃO NAS PASTAGENS BRASILEIRAS}

\begin{abstract}
RESUMO: As pastagens normalmente são associadas a menores problemas causados pela erosão devido ao fato de serem eficientes coberturas do solo, controlando bem as erosões em sulco e entresulcos. Mas, considerando a freqüência da renovação das pastagens cultivadas no Brasil e sua grande extensão territorial (178 milhões de hectares) é possível identificar que áreas expressivas, usualmente cobertas por pastagens, permanecerão descobertas e serão intensivamente preparadas sem nenhuma prática complementar de controle da erosão. Esta área equivale ao mesmo montante da área ocupada pelas principais culturas anuais (soja e milho) que são normalmente cultivadas em plantio direto ou suportadas por programas governamentais de conservação. A precisa avaliação desses impactos, causados pelos 10 milhões de hectares de pastagens em renovação anualmente, não é conhecida havendo grande carência de conhecimentos científicos para sugerir uma solução adequada. Este é, provavelmente, o grande desafio da conservação do solo no Brasil e necessitará, para adequada resolução, de um esforço conjunto de pesquisadores, técnicos, educadores e extensionistas.

Palavras-chave: impacto ambiental, pesquisa em conservação do solo
\end{abstract}

\section{INTRODUCTION}

Pastures are worldwide and for a long time considered a land use that protects against soil erosion. In the Land Capability Classification System suggested by Klingebiel \& Montgomery (1961), today still remaining a reference for conservation planning, pastures are recommended as an option for land that is not suited for annual crops because of restrictions related to soil conservation. The driving reasons for such an approach are that pastures in humid regions, provided they are not overgrazed or subjected to other degradation processes, offer permanent and complete soil cover, a deep and dense root system and prevent soil from direct exposure to wind and rainfall (SelfDavis et al., 2003; Santos et al., 1999; Aronovich \& Carvalho, 1993; Rodrigues \& Zevallos, 1991; Bertoni \& Lombardi Neto, 1990; Fontanelie \& Jaques, 1988; Dedecek et al., 1986; Willat \& Pullar, 1983). Ordinary soil conservation research related to pastures confirms soil protection and low soil erosion rates in established pasture conditions, evaluates the effects of pasture degradation on soil and nutrient losses, and off-site (externality) effects of manure and organic compound 
enrichment, and delivery from grazing areas (Walbrink et al., 2003; Nicholson et al., 2001; Stout et al., 2000; Warren et al., 1986a; 1986b; McGynty et al., 1978). In Brazil, soil conservation research related to pasture is scarce, but confirms low erosion rates and minor degradation processes. Pastures are never considered as a hot spot for erosion related off-site or local impacts (Souza, 2000; Santos, 1993; Dedecek et al., 1986; Eltz et al., 1977).

Brazil maintains agriculture or pastures covering approximately $27 \%$ of its territory. Pastures occupy most of these areas $(76 \%$ of the total agricultural land) and cultivated pastures (100 million hectares) prevail on rangeland (78 million hectares) (Table 1).

Considering the extensive land occupied by cultivated pastures in Brazil and the complete soil exposure during its seasonal renewal required for the incorporation of amendments and fertilizers, and seedbed preparation, soil erosion impacts associated to pastures can not be neglected. These impacts will affect especially more fragile soils and preserved environments, raising the damage potential of soil loss and off-site impacts. Such impacts have been overlooked because of the lack of research and awareness priorities of soil conservation related to pastures, inherited from the simplistic perception that pastures protect soils against erosion. This "Point of View" shows through evaluations and mapping the potential dimension of soil erosion impacts on Brazilian cultivated pastures as compared to main agricultural crops (soybeans and corn).

\section{Estimating and mapping pasture renewal}

The last available information on national scale of pasture coverage in Brazil was obtained from the survey made in 1995/96 during the National Census of Agriculture (IBGE, 1998). In this survey, pastures are classified as cultivated or natural. Natural pastures are composed of rangeland and the animals feed from native species. In natural pastures the soil cover is never totally removed and the eventual use of fire is always associated to the dry season, not coincident with intense rainfall.

Cultivated pastures prevail in more developed regions and better-suited climatic conditions. Soil is tilled (plowing or disking) for seedbed preparation, weed control, soil amendment and fertilization for pasture implantation and renewal. Large areas are usually tilled and prepared, considering that most machinery is heavy and rented because farms specialized in cattle are normally not equipped for these seasonal operations. Support practices such as terracing are also not frequently employed. Thus, during pasture seeding and reseeding large and contiguous areas are intensively tilled, remain uncovered, and stay under these conditions until the new seeds sprout and the crop is established.

The area of pastures of the National Census of Agriculture was aggregated at the municipality level and is represented in Figure 1a. The proportion of cultivated and natural pastures is also presented in Figures $1 \mathrm{~b}$ and $1 \mathrm{c}$. Pasture areas are represented as the percentage of municipal territory occupation.

Table 1 - Agricultural land use in Brazil.

\begin{tabular}{|c|c|c|c|}
\hline \multirow{2}{*}{ Land Use } & \multirow{2}{*}{ Area } & \multicolumn{2}{|c|}{ Proportion } \\
\hline & & Agricultural land & Territory \\
\hline & $10^{6}$ ha & - & - \\
\hline Cultivated Pasture $^{1}$ & 99.7 & 43.0 & 11.6 \\
\hline Rangeland $^{1}$ & 78.0 & 33.7 & 9.1 \\
\hline Soya beans ${ }^{2}$ & 16.4 & 7.1 & 1.9 \\
\hline Corn $^{2}$ & 12.3 & 5.3 & 1.4 \\
\hline Sugarcane $^{2}$ & 5.2 & 2.2 & 0.6 \\
\hline Beans (Phaseulus sp.) ${ }^{2}$ & 4.3 & 1.9 & 0.5 \\
\hline Rice $^{2}$ & 3.2 & 1.4 & 0.4 \\
\hline Coffee $^{2}$ & 2.4 & 1.0 & 0.3 \\
\hline Wheat $^{2}$ & 2.2 & 0.9 & 0.3 \\
\hline Cassava $^{2}$ & 1.7 & 0.8 & 0.2 \\
\hline Orange tree ${ }^{2}$ & 0.8 & 0.4 & 0.1 \\
\hline Cotton $^{2}$ & 0.8 & 0.3 & 0.1 \\
\hline Other agricultural land $u^{2} \mathrm{e}^{2}$ & 4.7 & 2.0 & 0.5 \\
\hline Total & 231.7 & 100.0 & 27.0 \\
\hline
\end{tabular}

${ }^{1}$ Source: 1995/96 Census of agriculture (IBGE, 1998). ${ }^{2}$ Source: Municipal agriculture production (IBGE, 2002). 
Pastures occupy significant areas all over Brazil, except for the Northern region, mostly covered by forests. In the Central-Western region the predominance is for cultivated pastures, while natural pastures dominate part of the Southern region (Pampas) and the transition of humid to semi-arid climate in the Northeast (Agreste). Probably, by updating the 1995/96 data for today, the share between cultivated and natural pastures may have increased, following a national trend of agricultural intensification. Also, the National Census of Agriculture 1995/96 covered only 54\% of the Brazilian territory, the remainder includes areas not surveyed (urban areas, natural forests, parks) but also remote areas, not reached by the survey; where extensive pastures prevail. Thus, the data shown graphically in Figure 1 and in Table 2 may be considered as a conservative projection of the occurrence of cultivated pastures in Brazil.

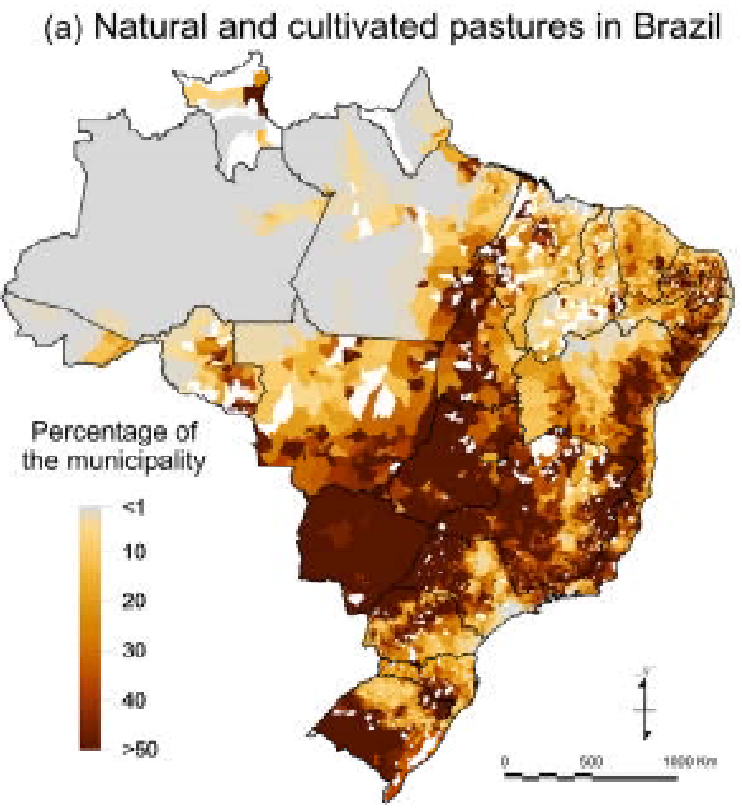

(b) Cultivated pastures
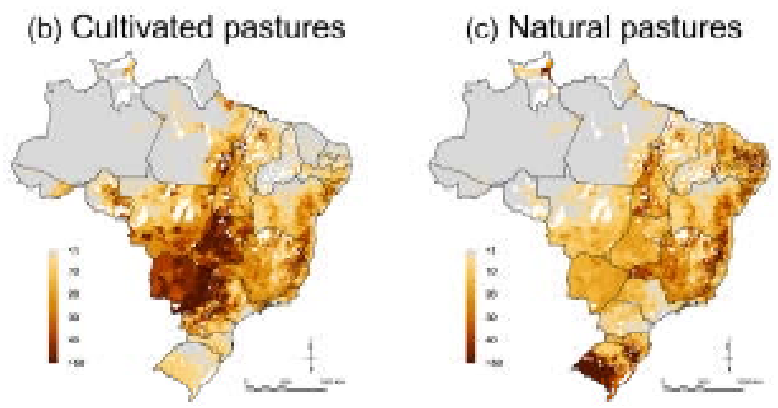

Figure 1 - Total, cultivated and natural pasture distribution in Brazil in relation to the municipal areas (1995/96 Census of agriculture, source IBGE, 1998).
Considering the state level, the area of cultivated pastures is greater than the sum of the areas of soybean and corn (main agricultural land use in Brazil, which combined represent $52 \%$ of the crop area excluding pastures) in all cases, except for the States of Ceará, Paraná, Rio Grande do Sul and Santa Catarina. The three last compose the South region, which is the most intensively cultivated part of Brazil. Figure 2 shows the area of pasture renewal by municipality and Table 2 gives the numerical data. The data are based on expert's opinions that pastures are reseeded about every ten years. The estimates are probably conservative because the conversion of range land (natural pastures, forests and savannas) into cultivated pastures were not taken into account when making the estimates.

More prevalence of pastures under renewal is observed in the Central-Western region of Brazil. Partially, also the states of the Southern part of Brazil present significant areas of tilled pastures. In the Amazon region remarkable areas can be observed only in the State of Rondônia. The estimated area of tilled pastures of 10 million hectares raises this kind of noneprotective land use condition to the same magnitude of the main crops: a) soybean 16 million hectares, and b) corn 12 million hectares. Using the appeal for better soil conservation during the last 20 years most of the areas cultivated with soybeans and corn have shifted from conventional tillage (plowing and disking) sup-

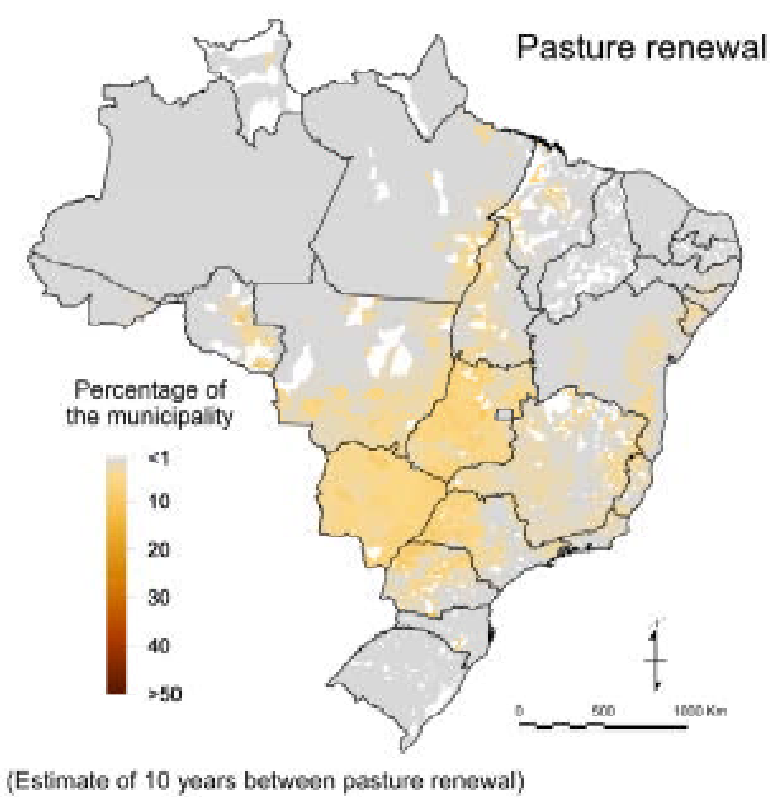

Figure 2 - Pasture renewal in relation to the municipal areas (1995/96 Census of agriculture, source IBGE, 1998) considering an interval of ten years of seasonal tillage for the cultivated pastures. 
Table 2 - Annual and permanent crops, corn, soybean, and pasture areas in Brazil.

\begin{tabular}{|c|c|c|c|c|c|c|c|}
\hline State & $\begin{array}{l}\text { Cultivated area with annual } \\
\text { and permanent } \text { crops }^{1,3}\end{array}$ & Soybean $^{1}$ & Corn $^{1}$ & $\begin{array}{c}\text { Natural and } \\
\text { cultivated pastures }\end{array}$ & $\begin{array}{c}\text { Natural } \\
\text { pastures }^{2}\end{array}$ & $\begin{array}{l}\text { Cultivated } \\
\text { pastures }^{2}\end{array}$ & $\begin{array}{c}\text { Estimated pasture } \\
\text { renewal area }\end{array}$ \\
\hline & & -- & $\cdots$ & $10^{3}$ ha - & --------. & $\cdots---$ & - - - - - \\
\hline Acre & 113 & 0 & 34 & 614 & 62 & 552 & 55 \\
\hline Alagoas & 685 & 0 & 69 & 862 & 490 & 373 & 37 \\
\hline Amapa & 14 & 0 & 2 & 245 & 219 & 26 & 3 \\
\hline Amazonas & 204 & 2 & 11 & 529 & 321 & 208 & 21 \\
\hline Bahia & 4,317 & 800 & 706 & 14,490 & 7,837 & 6,653 & 665 \\
\hline Ceará & 1,958 & 0 & 703 & 2,632 & 2,435 & 197 & 20 \\
\hline $\begin{array}{l}\text { Distrito } \\
\text { Federal }\end{array}$ & 90 & 38 & 27 & 96 & 34 & 62 & 6 \\
\hline Espírito Santo & 785 & 0 & 54 & 1,821 & 763 & 1,058 & 106 \\
\hline Goiás & 3,501 & 1,903 & 742 & 19,405 & 5,137 & 14,267 & 1,427 \\
\hline Maranhão & 1,327 & 238 & 315 & 5,311 & 2,404 & 2,907 & 291 \\
\hline Mato Grosso & 5,718 & 3,824 & 724 & 21,452 & 6,190 & 15,262 & 1,526 \\
\hline $\begin{array}{l}\text { Mato Grosso } \\
\text { do Sul }\end{array}$ & 2,104 & 1,196 & 491 & 21,811 & 6,083 & 15,728 & 1,573 \\
\hline Minas Gerais & 4,192 & 718 & 1,210 & 25,349 & 13,654 & 11,694 & 1,169 \\
\hline Pará & 1,119 & 3 & 275 & 7,456 & 1,631 & 5,825 & 582 \\
\hline Paraíba & 566 & 0 & 165 & 1,852 & 1,659 & 193 & 19 \\
\hline Paraná & 8,629 & 3,310 & 2,476 & 6,677 & 1,377 & 5,300 & 530 \\
\hline Pernambuco & 1,150 & 0 & 263 & 2,131 & 1,431 & 700 & 70 \\
\hline Piauí & 959 & 87 & 281 & 2,398 & 1,939 & 459 & 46 \\
\hline Rio de Janeiro & 255 & 0 & 11 & 1,545 & 901 & 644 & 64 \\
\hline $\begin{array}{l}\text { Rio Grande do } \\
\text { Norte }\end{array}$ & 485 & 0 & 103 & 1,246 & 1,158 & 88 & 9 \\
\hline $\begin{array}{l}\text { Rio Grande do } \\
\text { Sul }\end{array}$ & 7,480 & 3,307 & 1,465 & 11,680 & 10,524 & 1,157 & 116 \\
\hline Rondônia & 479 & 29 & 88 & 2,922 & 343 & 2,579 & 258 \\
\hline Roraima & 43 & 0 & 14 & 1,543 & 1,247 & 296 & 30 \\
\hline Santa Catarina & 1,730 & 244 & 834 & 2,339 & 1,779 & 560 & 56 \\
\hline São Paulo & 5,932 & 577 & 1,070 & 9,062 & 2,006 & 7,056 & 706 \\
\hline Sergipe & 324 & 0 & 100 & 1,154 & 625 & 529 & 53 \\
\hline Tocantins & 363 & 107 & 64 & 11,078 & 5,801 & 5,277 & 528 \\
\hline Total & 54,522 & 16,383 & 12,297 & 177,700 & 78,050 & 99,650 & 9,966 \\
\hline
\end{tabular}

${ }^{1}$ Source: Municipall agriculture production (IBGE, 2002). ${ }^{2}$ Source: 1995/96 Census of agriculture (IBGE, 1998). ${ }^{3}$ Source: Harvested area for permanent crops and planted areas for annual crops. ${ }^{4}$ Source: Considering an estimate of ten years between pasture renewal.

ported by terracing to no-tillage (Denardin et al., 2001). The adoption of no-tillage in the Southern part of Brazil has increased from an average of $20 \%$ in the 80 s to $90 \%$ in the $00 \mathrm{~s}$. A similar trend, but probably with slightly lower numbers, can be observed in all other annual crop's cultivated regions. The rationale for these is linked to reliable Research and Development (R\&D) improvements and diffusion by both, private (agricultural supplies companies) and public sections (research facilities, universities and extension services) favorable to no-tillage (Landers, 2001).

Thus, strong evidences suggest that pastures in renewal (considering the high efficiency of no-tillage in erosion control) are the main impacting land use promoting erosion and on-site impacts in Brazil. This conclusion contests the common sense of pastures being a protective land use type.

\section{Comparing pasture renewal and crops}

The relative importance of pasture renewal and agricultural land use was evaluated by dividing it by the area of corn (Figure 3a) and soybeans (Figure 3b) at the municipality level. Values of this ratio higher than 1 (green and blue color on the map) indicate the number of times the area of pasture renewal is greater than the crop in the municipality. The red colors indicate regions where the ration is lower than 1 , thus prevailing the crops. The extensive green and blue areas on the map indicate the areas where the main awareness 

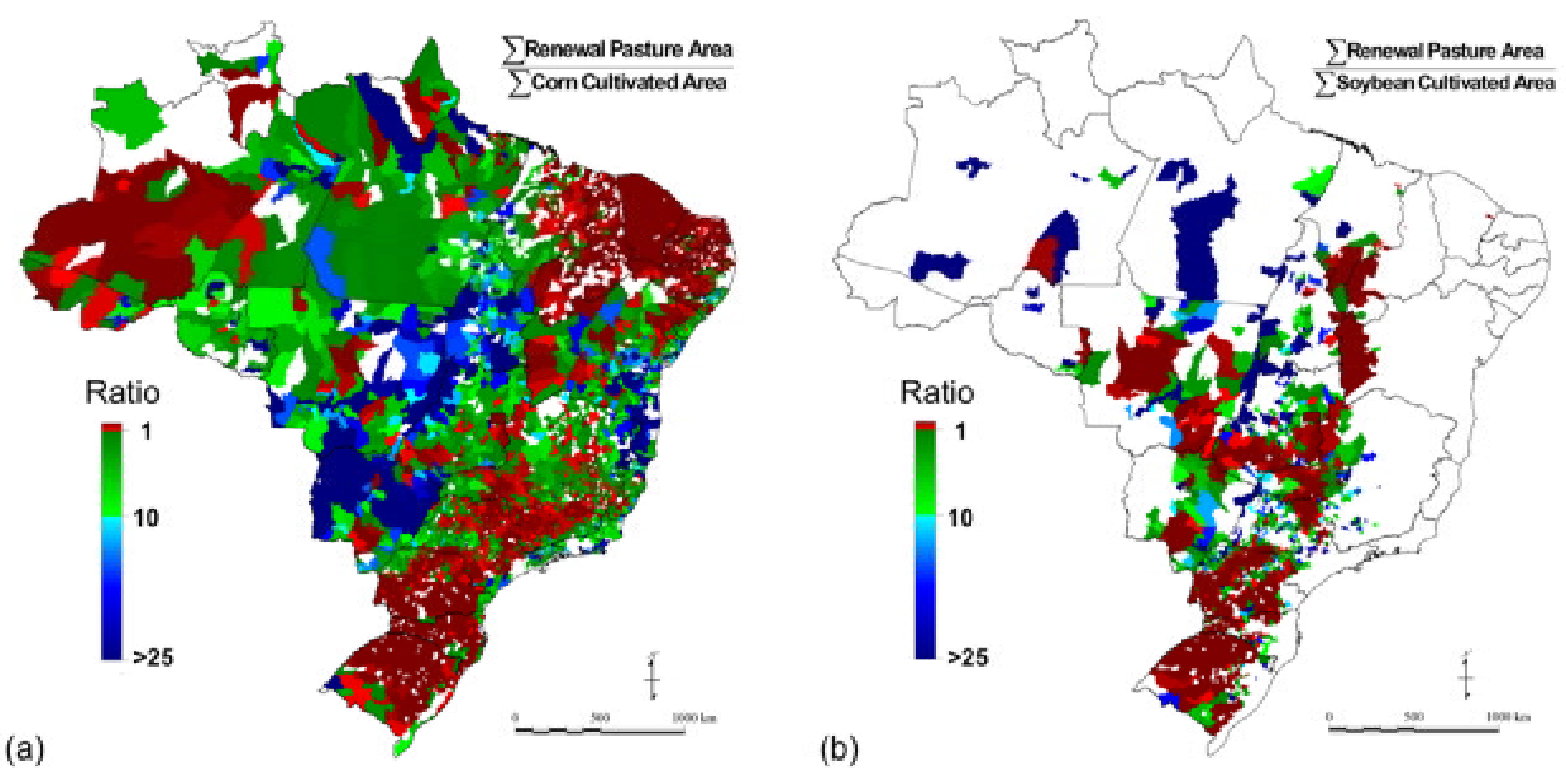

Figure 3 - Ratio between renewal pasture areas (considering an average renewal frequency of ten years and pasture areas in 1995/96 (1995/96 Census of agriculture, source IBGE, 1998) and corn (a) and soybean (b) cultivated areas (Municipal Agricultural Production in 2002, source IBGE, 2002).

in relation to soil erosion should focus on pastures and not on corn or soybeans. Although, R\&D creation and diffusion focus predominately on crops and marginally address to pastures.

\section{Potential impacts of soil erosion on cultivated pas- tures}

The impacts of soil erosion in pastures, considering the extension of 10 million hectares of pasture renewal per year and the large spatial dispersion of these areas, cannot be considered only locally. Especially the Central-Western region and large portions of the Southeastern region are threatened by erosion impacts by this kind of land use. Considering the relatively long period between pasture renewals (estimated in 10 years) short-term impacts on productivity should not be observable. Also, pasture renewal is usually combined with lime, gypsum or fertilizer application, which compensate for nutrient and productivity losses associated to soil erosion. Erosion induced productivity impacts in fertilized deep tropical soils may not be observed, even with high erosion rates, until soil depth or physical properties become restrictive (Sparovek \& Schnug, 2001, Sparovek \& De Maria, 2003).

The main impacts of soil erosion on tilled pastures will be associated to off-site (externality) impacts related to a) silting and sedimentation of water reservoirs and rivers that may contribute to river floods, freshwater degradation and life-time reduction of water dam facilities (Stout et al., 2000, Daniels \& Gilliam,
1996, Thurow et al., 1986); b) degradation of riparian areas and basin valleys (trapping regions of sediments) that can be related to wild-life and biodiversity destruction; and c) long term soil depth loss related to production sustainability (Clark et al., 1985). These impacts are not directly perceived at the farm production level.

\section{Conclusions, policy and research needs}

An important progress in soil conservation in Brazil was achieved by the large adoption of no-tillage in most annual crops. The reason for ignoring 10 million hectares of reseeded pastures per year, that are probably more susceptible to soil degradation than conventionally tilled crops and are in a more fragile environment, where pastures are large and in contiguous blocks; has to be understood before a policy to combat erosion can be designed. Part of this can probably be explained by the lack of concern of the private sector in acting in $\mathrm{R} \& \mathrm{D}$ creation and diffusion in processes that cannot be traded or appropriated (Alston \& Pardey, 1999). Corn and soybean no-tillage is pushed by a need for specific machines and supplies (herbicides) that attract private companies to the market. No such products can be related to the tillage and renewal of pastures by farmers. Fertilizers and soil amendments the farmer will use in any case when renewing pastures, with or without tillage.

Considering this market failure and excluding the private sector as a partner to create $\mathrm{R} \& \mathrm{D}$, enforce- 
ment, policy, and educational programs are the tools to face the problem. The rationale for a total disengagement of scientific institutions and staff with the subject and its non-consideration in any Brazilian public policy related to soil and water conservation may only be explained by the absence of perception and awareness of the problem. Basic research will have to cover the problem from the beginning, starting with comprehensive data on pasture renewal (frequency, locations, and management options) and passing through the option to avoid or reduce erosion impacts and soil loss in cultivated pasture implantation and renewal.

\section{REFERENCES}

ALSTON, J.M.; PARDEY, P.G. The economics of agricultural R\&D policy. In: ALSTON, J.M.; PARDEY, P.G.; SMITH, V.H. (Ed.). Paying for agriculture productivity. Baltimore: John Hopkins University Press, 1999. p.6-30.

ARONOVICH, S.; CARVALHO, S.R. As pastagens e a conservação do solo. In: REUNIÃO ANUAL DA SOCIEDADE BRASILEIRA DE ZOOTECNIA, 30., Rio de Janeiro, 1999. Anais. Rio de Janeiro: SBZ, 1993. p.341-351.

BERTONI, J.; LOMBARDI NETO, F. Conservação do solo. São Paulo: Ícone, 1990.

CLARK II, E.H.; HAVERKAMP, J.A.; CHAPMAN, W. Eroding soils. The off-farm impacts. Washington: The Conservation Foundation, 1985.

DANIELS, R.B.; GILLIAM, J.W. Sediment and chemical load reduction by grass and riparian filters. Soil Science Society of America Journal, v.60, p.246-251, 1996.

DEDECEK, R.A.; RESCK, D.V.S.; FREITAS JR., E. Perdas de solo, água e nutrientes por erosão em latossolo vermelho escuro dos cerrados em diferentes sistemas de cultivo sob chuva natural. Revista Brasileira de Ciência do Solo, v.12, p.265-272, 1986.

DENARDIN, J.E.; KOCHHANN, R.A.; FAGANELlO, A.; SATTLER, A. Evolução da área cultivada sob sistema plantio direto no Rio Grande do Sul. Passo Fundo: Embrapa Trigo, 2001. (Documentos, 29).

ELTZ, F.L.F.; COGO, N.P.; MIELNICZUK, J. Perdas por erosão em diferentes manejos de solo e coberturas vegetais em solo laterítico Bruno Avermelhado distrófico (São Jerônimo). I. Resultados do primeiro ano. Revista Brasileira de Ciência do Solo, v.1, p.123-127, 1977.

FONTANELIE, R.; JACQUES, A.V.A. Melhoramento de pastagem nativa: ceifa, queima, diferimento e adubação. Revista da Sociedade Brasileira de Zootecnia, v.17, p.180-194, 1988.

INSTITUTO BRASILEIRO DE GEOGRAFIA E ESTATÍSTICA. Censo Agropecuário 1995-1996. Rio de Janeiro: Fundação IBGE, 1998.

KLINGEBIEL, A.A.; MONTGOMERY, P.H. Land capability classification. Washington, DC.: USDA, 1961. (Agricultural Handbook, 210).

LANDERS, J.N. How and why the Brazilian zero tillage explosion occurred. In: INTERNATIONAL SOIL CONSERVATION ORGANIZATION MEETING, 10., Purdue, 1999. Sustaining the global farm. Washington: USDA, ARS, 2001. p.29-39.
MCGYNTY, W.A.; SMEINS, E.E.; MERRILL, L.B. Influence on soil, vegetation and grazing management on infiltration rate and sediment production of Edwards Plateau Rangeland. Journal of Range Management, v.32, p.33-37, 1978.

NICHOLSON, C.F.; BLAKE, R.W.; REID, R.S.; SCHELHAS, J. Environmental impacts of livestock in the developing world. Environment, v.43, p.7-17, 2001.

RODRIGUES, A.C.G.; ZEVALLOS, A.C. Efeito da intensidade de pastejo sobre o sistema radicular de pastagem. Pesquisa Agropecuária Brasileira, v.26, p.439-445, 1991.

SANTOS, D. Perdas de solo e produtividade de pastagens nativas melhoradas sob diferentes práticas de manejo em Cambissolo distrófico (epiálico) dos Campos da Mantiqueira (MG). Lavras: UFLA, 1993. (Dissertação - M.S.).

SANTOS, P.M.; CORSI, M.; BALSALOBRE, M.A.A. Efeito da freqüência de pastejo e da época do ano sobre a produção e a qualidade em Panicum maximum cvs. Tanzânia e Mombaça. Revista Brasileira de Zootecnia, v.28, p.244-249, 1999.

SELF-DAVIS, M.L.; MOORE, J.P.A.; DANIEL, T.C.; NICHOLS, D.J.; SAUER, T.J.; WEST, C.P.; AIKEN, G.E.; EDWARDS, D.R. Forage species and canopy cover effects on runoff from small plots. Journal of Soil and Water Conservation, v.58, p.349359, 2003.

SOUZA, Z.M. Propriedades físicas e químicas de um latossolo vermelho escuro de Selvíria-MS sob diferentes usos e manejos. Ilha Solteira:UNESP, 2000. (Dissertação - M.S.).

SPAROVEK, G.; DE MARIA, I.C. Multiperspective analysis of erosion tolerance. Scientia Agricola, v.60, p.409-416, 2003.

SPAROVEK, G.; SCHNUG, E. Temporal erosion-induced soil degradation and yield loss. Soil Science Society of America Journal, v.65, p.1479-1485, 2001

STOUT, W.L.; FALES, S.L.; MULLER, L.D.; SCHNABEL, R.R.; ELWINGER, G.F.; WEAVER, S.R. Assessing the effect of management intensive grazing on water quality in the northeast U.S. Journal of Soil and Water Conservation, v.55, p.238245, 2000.

THUROW, T.L.; BLACKBURN, W.H.; TAYLOR JR., C.A. Hydrologic characteristics of vegetation types as affected by livestock grazing systems. Journal of Range Management, v.39, p.505-509, 1986 .

WALBRINK, P.J.; MARTIN, C.E.; WILSON, C.J. Quantifying the contributions of sediments, sediment-P and fertilizer-P from forested, cultivated and pasture areas at the landuse and catchment scale using fallout radionuclides and geochemistry. Soil \& Tillage Research, v.69, p.53-69, 2003.

WARREN, S.D.; BLACKBURN, W.H.; TAYLOR JR., C.A. Effects of season and stage of rotation cycle on hydrologic condition of rangeland under intensive rotational grazing. Journal of Range Management, v.39, p.486-490, 1986 a.

WARREN, S.D.; NEVILL, M.B.; BLACKBURN, W.H.; GARZA, N.E. Soil response to trampling under intensive rotation grazing. Soil Science Society of America Journal, v.50, p.1336$1341,1986 \mathrm{~b}$

WILlATT, S.T.; PULLAR, D.M. Changes in soil physical properties under grazed pastures. Australian Journal of Soil Research, v.22, p.343-348, 1983.

Received April 06, 2006

Accepted November 17, 2006 